\title{
The Perils of Proximity: The Geopolitical Underpinnings of Australian Views Of New Caledonia In The Nineteenth Century
}

\author{
Elizabeth Rechniewski, University of Sydney
}

The close relationship that once existed between these far-flung outposts of European empire has largely been forgotten, yet in the nineteenth and early twentieth centuries New Caledonia loomed large in Australian preoccupations and imagination. The links between these two imperial colonies were much stronger than we might realise today: a web of interdependent commercial and personal relations underpinned a complex relationship that oscillated between rivalry, suspicion and the recognition of interests held in common by European settlers who were each other's closest neighbours. These attitudes reflected in part the state of broader relations between France and Britain, as well as changing geopolitical realities in the region. The profoundly ambiguous and tension-filled relationship between the two imperial powers, Britain and France, must be stressed-the two countries had been at war for much of the past five hundred years; they vied for power and influence in Europe, strategic control of international waters and colonial possessions; yet they recognised one another, in relation in particular to the indigenous other, as sharing European, Christian, civilised values. The alliance between France and Britain forged to fight the Crimean war in 1853-the year of the French takeover of New Caledonia-did not fundamentally alter the suspicion that many Australians felt towards the French. Indeed, they feared that the British would be all the 
more likely to abandon the interests of their colonial dependents if those interests conflicted with the needs of the alliance.

In addition to being buffeted by these centuries-old antagonisms between the imperial powers, relations between the Australian colonies and New Caledonia reflected the more particular situation of European settlers who were forging colonial societies in a region very remote from the tutelage of the metropole. The 'tyranny of distance' had a special impact on the mindset of Australians, who feared that the relative proximity of New Caledonia and their own isolation from possible British intervention made them vulnerable to any threats that might come from that quarter. Jill Donohoo has recently shown convincingly how attitudes towards the presence of a penal colony in New Caledonia, and the 'danger' posed by escaped or pardoned prisoners arriving on Australian shores, helped to shape Australia’s fledgling foreign policy, its evolving relationship with Britain, and even the push towards Federation (Donohoo 2013). This article focuses on other perceived dangers posed by the proximity of New Caledonia through exploring attitudes and opinions expressed in the Australian press at certain key points in New Caledonia's history: the annexation of the Grande Terre by the French in 1853, the Kanak revolts of 1878-1879 and the pre-World War 1 nickel mining boom.

The tangled attitudes expressed in the Australian press towards New Caledonia cannot be understood without recalling the early years of its settlement. From the founding of the colony of New South Wales, New Caledonia was under the titular control of the colonial administration, whose charter laid claim to seas within 30 degrees of the coast. Although the islands were not officially settled by the British, Australian merchants set up a triangular trade between New Caledonia, Australia and China, transporting iron and metal utensils and tools of many kinds and tobacco to New Caledonia to trade for sandalwood, which they took to China and traded for tea that was then brought back to Australia. Australian sandalwood merchants, writes Martyn Lyons, were 'by far the most frequent and representative visitor[s] from Australian shores in this period' (Lyons 1986: 8). At first a trickle, the trade took off in the 1840s: between 1840 and 1850, traders operating out of Australia stripped sandalwood first from the île des Pins, then the Loyalty Islands and finally Grande Terre's east coast. They also collected bêches-demer (Trepang or sea cucumbers). The Loyalty Islands and in particular the coast around Ouvéa saw extensive trade exchanges between the islanders and English-speaking 
merchants. English was the first European foreign language the natives heard, some English words entered their languages, and a pidgin 'bichelamar' (from the word for Trepang), a mixture of English and local languages developed. In 1879, in his report on the Kanak revolts, General de Trentinian notes that 'les Canaques parlent l'anglais de préférence au français ${ }^{1}$ (Dousset-Leenhardt 1978: 146).

This language work was promoted by Protestant missionaries who were the first missionaries to arrive on New Caledonia in 1840, three years before the Catholics, and they appear to have been considerably more successful than the Catholics in those areas, the Loyalty Islands (Maré and Lifou), where they were allowed to continue their mission after the French annexation of the main island. Only at the very end of the nineteenth century were they permitted by Governor Feillet to re-establish themselves on the mainland. However in the Loyalty Islands they wielded considerable influence through the education of new generations, forming a strong Protestant presence on the islands that will be reflected in the story of Watriama, later in the article. Later in the century some of these missionary settlements would be accused by the French of running a kind of fiefdom, beyond the reach of civil law, and of fomenting opposition to French administration (Lyons 1986: 34-35).

One of the early names given to the group of islands off the east coast of New Caledonia—including Ouvéa, Maré and Lifou—was ‘the Britannia Group,' named after a British trading vessel 'Britannia' that called there in 1793 (the same year as the passage of D'Entrecastaux). This appellation was still in use in newspapers published in New South Wales and Victoria in the 1840s, with the associations of assumed ownership that this implies (MM 09.12.1843: 3; AUST 30.09.1843: 4). A few Australians and Britons settled in New Caledonia and set up businesses: Mr Towns, a 'respectable man in Sydney' on the Isle of Pines, for example (SMH 25.01.1851: 6), and James Paddon, a British adventurer turned trader, who bought the island of Nou from the chiefs in 1851 and established trading posts along the east and west coasts of the Grande Terre. At the time of the French annexation he ran a highly flourishing business employing hundreds of native and European workers, with his own shipping fleet, shipyards, and a village at Anse Paddon with shops and services.

\footnotetext{
1 'The Kanak prefer to speak English rather than French.'
} 
For many decades after the founding of New South Wales, therefore, Australian merchants and missionaries considered New Caledonia as their own 'hunting ground' and the general public were accustomed to think of it as an offshore appendage. News from and about New Caledonia, particularly the arrival and departure of trading vessels, weather and sea forecasts, were a regular presence in the early newspapers. This early history contributed to the sense of ownership that Australians continued to express throughout the century, challenging the legitimacy of French control. For despite some impractical propositions and failed private initiatives to extend British colonial administration over New Caledonia, such as that of Major Sullivan, a retired army office resident in New South Wales who in 1842, 'proposed to establish a settlement at New Caledonia to be called Victoria in honour of the Queen'², the British failed to secure the islands.

\section{French Annexation, 24 September 1853}

In September 1853, two ships of the French navy landed at Balade and claimed possession in the name of Emperor Napoleon III. The annexation provoked outrage in the Australian colonies; this outrage however was directed as much against the British colonial office for its laxity and lack of foresight as criticism of the French for their boldness. Note that it came 11 years after the French annexation of Tahiti and the 'Pritchard affair' of 1842 - the expulsion of the British missionary and Consul George Pritchard - which provoked lingering poor relations and suspicion between France and Britain during the reign of Louis-Philippe and also suggested to the Australians that the British might be less than forceful in protecting British colonial possessions. In relation to that incident, the South Australian Register wrote that 'French activity and aggrandisement have prevailed against the rights of a defenceless Christian Queen who from English fainéantise and over-cautious policy is left unprotected' (SAR 05.06.1844: 4). France had also extended her influence in the Gambier Islands, Tuamotus and Wallis and Futuna, 'becoming England's principal colonial rival in the South Pacific' (Merle 1995: 35).

\footnotetext{
${ }^{2}$ Mills relates that a company was to be formed under royal charter with a capital of 3,000,000 British pounds, to buy lands from the Crown at 5 shillings per acre and to use the proceeds to promote Asiatic or convict emigration until free Europeans became acclimatised. The Colonial Office 'rightly dismissed the plan as visionary and impracticable' (Mills 1915: 314).
} 
News of the French takeover apparently reached Australia only at the end of October, since 1 November is the first date on which a report appears in the Australian press, in the Sydney Morning Herald. Over the following days the newspapers lament the fact and assess the consequences of this event of 'very grave importance,' this 'coup d'état' in the words of the Maitland Mercury (19.11.1853: 2), this 'bold move' that indicates 'ambitious projects' on the part of the Emperor, which he has been at pains to conceal (CH 12.11.1853: 2). The Australian press-which often summarises and relays each other's articles-expresses in chorus ideas that are to have a long life.

They insist that New Caledonia rightfully belongs to Britain—Cook had hoisted the Ensign in 1774 and had provided a detailed description of the place (Cook's account of his landing is republished in a number of newspapers to support this prior claim). With the benefit of hindsight, and a new appreciation of what has been lost, the papers lament the capture of this 'valuable prize,' making frequent references to its economic and strategic significance. France is said to have seized it in compensation for the 'loss' fifty years previously of St Domingo, 'the only really valuable colony they ever had' according to one correspondent (CH 09.12.1853: 2). Having recently forfeited New Zealand to the British, according to a letter writer to the Sydney Morning Herald, the French sought first a port on Tahiti but finally settled on New Caledonia: the port of St Vincent is a 'Cherbourg in the Southern Hemisphere’ (SMH 03.11.1853: 3).

The laxity of the British government is responsible for allowing the French takeover. The Australian press castigates the 'cowardly spirit of the Cabinet at home' (SMH 03.11.1853: 3), the 'idly neglectful' colonial authorities, the 'doubters of Downing Street’ (MM 19.11.1853: 2). Their negligence is contrasted to the purposefulness, planning and decisiveness of the French, who displayed 'the practical genius of the Tuileries' (MBC 19.11.1853: 2). A sense of betrayal is pervasive: doubts are expressed as to whether the Colonial Office has the interests of the colonists at heart or the will to defend them for it is too preoccupied by grand designs and imperial alliances. A letter writer to the Sydney Morning Herald assets that 'If Australia were a nation, there can be no doubt how she would act in the matter; the French occupation would be resisted as an aggression'; Australia, however, is in a weak position to object since the French, dealing only with Britain, can claim that they are as near to New Caledonia as the British are (SMH 09.11.1853: 3). The alliance between Britain and France-which has 
perhaps stayed a British response to this affront-is often represented as unnatural, an act of cowardice: 'the unnatural and unholy alliance that now exists between England and France, between liberty and despotism, between light and darkness; between fraud, perjury, and murder on the one side, and truth, honour, and philanthropy on the other' (ISN 12.11.1853, reprinted in MBC 26.11.1853: 4). French motives are suspect, its plans for the future of the island viewed with grave concern. If the aim of the takeover is to set up a penal colony (this 'moral pestilence’), the commentators are outraged: just when New South Wales has rid itself of its 'bad reputation consequent on being a penal colony,' just when transportation has been stopped, a new colony may be set up in her near neighbourhood, and on the trade routes with the West Coast of America, China etc. (ISN 12.11.1853, reprinted in MBC 26.11.1853: 4). As Donohoo has shown, there was both initial and ongoing concern that escaped convicts might make their way to Australia.

Other, more sinister, motives are imputed to the French: it cannot be simply to set up a penal colony that France has gone to this much effort, the annexation must be part of her larger strategic designs for control of the Pacific. Louis Napoléon’s 'ambitious projects' writes the Courier Hobart, which have been pursued quietly, even behind 'a veil' are now coming to fruition (CH 12.11.1853: 2). The Moreton Bay Courier, displaying a decided taste for the colourful turn of phrase and the sensational claim, avers that Louis Napoléon's plans put the whole of Eastern Australia and New Zealand under threat from a 'swarm of the mustachioed sons of Gaul':

\footnotetext{
New Caledonia occupies a most commanding position for a naval station, whence, in the event of occasion arising, all the ports of Eastern Australia and New Zealand could be commanded within a week. Balade Harbour is situated in latitude $20^{\circ} 17^{\prime} 25^{\prime \prime}$ S., longitude $164^{\circ} 27^{\prime}$ E. A good steamer, or a north-easterly breeze, would easily bring swarms of the mustachioed sons of Gaul, into Moreton Bay for instance, in four or five days. (MBC 19.11.1853: 2)
}

The Courier points to the additional cost of the defence measures made necessary by the French presence, to protect 'England's wealthiest and most defenceless possessions' (MBC 19.11.1853). In the event of war between Britain and France, the port (then Port St Vincent, 25 miles north-west of Noumea) would allow the French to control access to Port Jackson: it is 'admirably situated to enable them to capture every vessel entering or leaving the ports of New South Wales' (CH 9.12.1853: 2). Occasional and unfounded 
reports of the French building a 'second Sebastopol' in New Caledonia contribute to this fear (SAA 20.08.1860: 2).

These fears were not expressed only on the wilder fringes of the Australian press: on 20 December 1859 Sir Henry Parkes moved a resolution in the NSW Legislative Assembly, 'The Defence of the Colonies,' calling for the formation of a national militia to defend the colony from attack by aggressive European powers. It soon becomes clear in his speech that he has in mind the threat posed by France, a threat that was all the greater because they had 'a port of refuge within a very few days' sail of our own harbour, 'as contiguous to our shores as an enemy could wish it to be’ (Parkes 1876: 103). Declaring that the danger of a rupture with France was imminent, he warned that protection could not be expected from Britain since the 'Imperial government has directly intimated on more than one occasion that the colonies must provide for their own defence' (Parkes 1876: 98, 103).

The ambiguity of the relationship to this foreign power-now after all an ally of Britain in the Crimean war-and the self-interest of the colonists who traded extensively with New Caledonia, allow calmer voices to be heard. Despite conjuring up hysterical visions of swarms of marauding Gauls, the Moreton Bay Courier sees reason to be optimistic about the economic and possibly even the military advantages of the takeover. The presence of the French will probably 'induce our Admiralty to post a strong naval squadron in the Pacific,' using one of the Australian ports. Scientific exploration may be pursued and goldfields discovered in New Caledonia. Adopting a decidedly parochial approach to international affairs, it opines that in the event of the continuance of peace, the French colonists will need livestock and coal, thus providing a 'profitable outlet within four or five days sail of Moreton Bay’ (MBC 19.11.1853: 2). The Maitland Mercury, paraphrasing the Sydney Morning Herald of 1 and 2 November, argues however that while, from a commercial point of view, the annexation-'even by the French' - may seem advantageous, this is far outweighed by 'the moral, social, and political consequences attaching to the occupation of one of the most splendid islands in the Pacific by a rival nation, whose aims and objects are so dissimilar, not to say opposite, to those which have for many years been earnestly contemplated by the most intelligent colonists of Australia and New Zealand’ (MM 5.11.1853: 3). 
The Moreton Bay Courier sees other reasons to hope: many places that were formally under French or Spanish control are now British. In the event of war between Britain and France it is possible that New Caledonia might change hands ... although the paper sagely hopes that such conflict can be avoided: 'The two most powerful and enlightened nations in the world, have been long enough at war with each other' (MBC 19.11.1853: 2). The Illustrated Sydney News, although uncompromisingly anti-French, takes a similarly confident view of the power of the British - the strongest naval power on earth-to evict the French from the Pacific in the event of war between the two nations. The French settlers should therefore perhaps be considered as 'pioneers' doing the rough work of clearing the land before it reverts to the British (ISN 12.11.1853: 1, reprinted in MBC 26.12.1853: 4). \%

It is in this paper that the first hints of a particular critique of the French begin to be seen. The Illustrated Sydney News states that it is not optimistic about the fate of the natives of New Caledonia under French rule, and doubts whether any improvement in their lot can be hoped for under their new Gallic masters:

Profligate in life, corrupt in morals, servile in spirit, and degraded in politics, the French are
about the last people on the face of the earth whose rule it would be desirable to substitute
for any other government that could be mentioned. The fact is that the French and the
savages, placed at opposite extremities of the same line, are both equally remote from the
golden mean of true civilisation: and, indeed, if forced to choose between the two, we would
prefer immaturity to rottenness. (ISN 12.11.1853: 1, reprinted in MBC 26.12.1853: 4)

The virulence of this denunciation (of an ally) might seem to be a marginal opinion and no doubt was the most extreme of its kind. However it is worthy of note that this article was reprinted in the Moreton Bay Courier on 26 November.

The arguments put forward in the newspapers in November and December 1853 constitute so many 'frames, 3 that will be used to interpret French motives and actions, to diagnose problems and even to pass moral judgement on the French as colonial neighbours, over the next sixty years. Business being of greater long-term interest than politics, however, despite the fears expressed concerning the effects of French annexation, Australian involvement in the colonial development of New Caledonia continued apace: an Australian, John Higginson, became the largest owner of copper

\footnotetext{
${ }^{3}$ For Kuypers, 'Framing ... is the process whereby communicators act-consciously or not—-to construct a particular point of view that encourages the facts of a given situation to be viewed in a particular manner, with some facts made more or less noticeable (even ignored) than others' (Kuypers 2009: 182).
} 
and nickel mines, exported gold from Fernhill mine and founded what later became the Société le Nickel. Cattle were brought to New Caledonia from Australia and put out to graze using Australian methods of pasturing (large unfenced pastures) causing untold damage to the terrain and colliding with the agricultural interests of the Kanak as the cattle trampled over their crops. Australian words entered the French language on New Caledonia: les stockmen; les paddocks; le bush, reflecting the extensive participation of Australians in the cattle industry: 'In 1866 there were 200 Australians in New Caledonia out of a population of 1100 free settlers. The Franco-Australian society was a substantial livestock company’ (Lyons 1986: 49-50). It was however a very one-sided arrangement: in 1860, trade with New Caledonia amounted to only 1 percent of Sydney's foreign trade, but exchanges with Sydney amounted to no less than 84 percent of New Caledonia's trade (11).

\section{The Kanak Revolts of 1878-1879}

The second significant period examined in this article concerns the revolts by certain Kanak tribes against French rule in 1878-1879. By this time the penal colony had been functioning for some 12 years and two significant groups of political deportees had arrived there in the 1870s: 200 or more Kabyl Algerians deported in 1873 after the Mokrani uprising and some 4,000 Communards (estimates of numbers for both groups vary considerably). George Parsons and Jill Donohoo have written of the hostile reactions expressed in the press and parliaments of NSW and Queensland during this period to the possible arrival of pardoned Communards and prisoners whose sentence had expired, as well as the ongoing threat of escapees from the penal colony; and of the attempts by the colonial governments to prevent their entry. From the mid-1870s, writes Parsons, this issue provoked 'a diplomatic quarrel between Great Britain and France, and 'arous[ed] intense feeling in the Australian colonies' (Parsons 1967: 58). It is important to recognise that this issue was an ongoing source of tension in the views held by Australians towards the French colony, but our focus here is on the reaction to the indigenous revolts that were extensively covered in the Australian press. ${ }^{4}$ This reaction must be understood in the context of the developing imperial rivalry, where the issue of who might make the 'better' colonisers became an argument in justification of the legitimacy of British rule. References abound in the papers of this period to the defects

\footnotetext{
${ }^{4} 200$ French and 1200 Kanaks, including Atai and several other chiefs, were killed. As a result of the rebellion, 800 Kanaks were exiled to either the îles Belep or île des Pins. Others were sent to Tahiti, never to return.
} 
of French colonial rule, whether in the colony of Bourbon (present-day Réunion) where ‘chaos’ prevails (SMH 20.08.1879), or in Cochin-China (EN 27.03.1878: 2). The 'unfortunate state of affairs in New Caledonia,' brought about by mining failures and financial disasters, is 'but a type of the wretched state of French colonies generally' (EN 27.03.1878: 2).

This rivalry helps to explain the nature of the reporting of the Kanak revolts. The descriptions of the rebel natives as 'blood-sated murderers' who leave 'corpses lying in every direction, cut and hacked as savages delight to do’ (SMH 12.07.78: 5) reflect the fellow colonists' horror at the 'barbarity' of the natives. Oblique references to the mutilation of bodies 'too revolting and sickening to describe here' (MM 13.07.78: 6) hint at acts of cannibalism that, as Karin Speedy has shown, operated as the demarcation between savage and civilised (Speedy 2013). However it is noteworthy that considerable attempts are made nevertheless to explain the origin of the events in grievances held by the Kanak against the settlers or the French authorities, grievances that, it is often suggested in the Australian press, are well founded. Whatever the excesses of the tribes' actions, these are shown to be motivated by affronts to their customs, by land disputes, forced labour or the result of mistreatment and exploitation. The article in The Maitland Mercury (13.07.1878: 6) is clear in attributing blame to the colonial administrators, particularly a certain Lecarte, and to the settlers who had encroached on native land, had 'tampered with their women' and dug up Kanak graveyards. The Brisbane Courier, while attributing to the race of the Papuan (sic) family of mankind 'all its worst characteristics,' nevertheless reflects in philosophical vein that we have no means of knowing the native version of the events: 'The white man writes his own annals; the savage passes away and leaves no record' (BC 15.10.1878: 2).

The Sydney Morning Herald sent its own correspondent, a certain 'Julian Thomas' (he had changed his birth name ‘John Stanley James’ several times), known as The Vagabond, a journalist who, after working in London, New York and Melbourne, had moved to Sydney in August 1877 and begun to write for the Sydney Morning Herald with articles notably about Sydney’s slums. In Melbourne he had gained notoriety for investigative methods that saw him adopt the persona of a down and out in order to expose the wretched lives of the underclass. Sydney readers were less interested in such 
exposés; the editor therefore sent him to New Caledonia in July 1878 as its 'Special Correspondent' to report on the native revolts there (Cannon 1983: 9). He was perhaps Australia's first 'war correspondent,' indeed he referred to the indigenous revolts as a 'war.' Thomas sent back reports that, he later discovered, were often withheld by the French authorities. Only on his return was he able to rewrite and publish lengthy accounts of the war, reprinted in other Australian papers, from the beginning of September until the end of October 1878.

Thomas gained a close understanding of the causes and consequences of the war for he was granted special permission by the French governor to travel to the districts in revolt; he accompanies the French troops on patrol, describes in vivid detail the exhaustion and privations of these marches, interviews officers, colonists, residents of Noumea and even a few indigenous people. He tries to uncover and explain for his readers what has provoked the revolts, and lays out in great detail the depradations, exactions, and humiliations that colonisation and settlement have imposed on the native peoples (article dated 27.09.78; printed SMH 15.10.78). He catalogues the massacres committed by the rebels, but also the sometimes indiscriminate retribution inflicted by the troops, and especially the gendarmes. He is also critical of the authorities' lack of preparedness, their failure to warn or come to the assistance of isolated settlers who stand in peril. Michael Cannon describes his reports as constituting 'one of the first and most damning indictments written against French colonial rule in the Pacific' (Cannon 1983: 10). It is perhaps significant to note, however, that when Thomas was asked by The Argus in 1883 to report on the system of 'blackbirding'-forced recruitment of indigenous workers from the New Hebrides to work on Queensland sugar plantations - he had little criticism to make of a system that was nevertheless akin to slavery (Pons-Ribot 1989: 15).

This hint of a double standard echoes the readiness to condemn French colonialism and exonerate British practices that is widespread in the newspapers of the time. The Brisbane Courier correspondent, recognising the universal significance of the conflict over land between coloniser and colonised, offers a well-developed if tendentious comparison:

In Australia the very sparseness of the population, both black and white, operates to prevent collisions on so grimly murderous a scale as the one reported from New Caledonia; while in New Zealand the mixture of braggadocio and magnanimity that characterises the Maori 
warrior has been, even in the thick of bush warfare, a better protection to the settled districts than the bullets of her Majesty's red-coats. In New Caledonia, on the other hand, both these conditions are reversed. There is a teeming native population, brooding over their territorial wrongs while closely mingled with and pressed on by a still greater force of whites. (BC

03.08.1878: 4)

The journalist draws a contrast between the colonising practices of the British in Australia and the French in New Caledonia, to the disadvantage of the latter. Whatever may be the faults of the British colonists, the French have dealt with their natives in a worse fashion. The Kanak are actually more civilised than the completely savage Aborigines: they live in settled villages, till the soil, venerate their chiefs, and have a system of landownership, and yet the French have treated these 'semi-civilised tribes' worse than we have the 'wholly savage' Australian natives (BC 26.11.1878: 2).

Such criticisms of the failures of French administration and colonisation - the 'admitted incapacity of our French neighbours for the work of colonisation' as The Brisbane Courier puts it (26.11.1878: 2) - generally draw a distinction between the role of the authorities and that of the white settlers, the latter often portrayed as the victims of the incompetence of their officials. This distinction allows the newspapers to once again argue that New Caledonia should be handed back to the British, thus 'relinquishing to abler or more experienced hands the uphill task of colonising and civilising New Caledonia’ (BC 07.09.78: 4) and also for a certain fellow feeling to be evinced in sympathy with the plight of the French settlers, linked after all to Australians by personal and commercial ties, and sharing the 'white man's burden' in these farflung imperial outposts. On a personal level, 'generous sympathy' and support for the French settlers is expressed through a subscription fund that raised a little over 620 pounds (SMH 10.08.1878: 4).

The claim that the majority of French settlers would be glad to have the British as colonial masters is once again advanced: 'such a desire, it is credibly reported, has for some time past been very generally felt by those settlers who are competent to form an opinion concerning the future prospects of the island under French rule' (BC 07.09.1878: 4). ${ }^{5}$ This long-standing (and largely unsubstantiated) claim in the

\footnotetext{
${ }^{5}$ Note that in the French report into the causes of the revolts, General Arthur de Trentinian cited as one of the causes: 'le profond sentiment de jalousie avec lequel les Anglais ont vu et voient encore notre occupation de la Nouvelle-Calédonie'(the profound feeling of jealousy with which the English have viewed and still view our occupation of New Caledonia), a sentiment which has led them to 'encourage' the natives of New Caledonia to profit from the military weakness of France in the wake of the 1870
} 
Australian press is one that will continue to be aired into the twentieth century, when it will again become entangled in fears of invasion-no longer fear of invasion from the French but from the North, when New Caledonia is seen to represent the 'weak link' in Australian defence and the stepping stone for possible invasion by the Japanese.

\section{Pre-World War I}

The final period examined in this article are the two decades preceding World War I, a period of renewed Australian interest in New Caledonia in the context of the perceived threat from Japan. Many writers have drawn attention to the increasing anxiety about the growing economic and military power of Japan in the Pacific at this time (Walker 1999; Meaney 2007), anxiety fuelled by her victory over Russia in the war of 1905, the first victory of an Asian power over a European one in modern history. From this time on, although Japan was allied to Britain from 1902, Australia viewed Britain’s Asian ally as a potential enemy and Japan became an object of 'obsessive interest' for Australians (Stanley 2008: 27). The fear of invasion and a burgeoning race fear found expression in poetry and fiction and in the new and striking medium of film. This was not a marginal phenomenon: influential magazines such as the Bulletin and many lesser pamphlets and journals such as The Lone Hand contributed to fostering this fear.

In this context the proximity of New Caledonia took on a new significance. Large numbers of Japanese workers, perhaps two thousand by some estimates, had been recruited from the late nineteenth century to work in the booming nickel mines there. ${ }^{6}$ But were they simply workers or was something more sinister going on? Might this colony not constitute a jumping off point for the invasion of Australia? Typical of the wilder claims made about the danger posed by the presence of Japanese workers on the Grande Terre was the article by A. K. Shearston-May: 'New Caledonia: A Menace to White Australia: the remarkable colony of Japanese who have become Australia's nearest neighbor,' published in The Lone Hand in June $1911 .{ }^{7}$

Shearston-May, who had recently visited the island, claims the presence of some 2,500 Japanese workers on New Caledonia, many of them former soldiers who had fought in

defeat by Germany (Appendix, Dousset-Leenhardt 1978: 146). De Trentinian offers no evidence of such interference in the colony however.

${ }^{6}$ This was a significant number compared to the population of the colony at the time, perhaps 60,000 in total, including 27,000 Kanak, Europeans (convicts and settlers) and workers from other islands.

${ }^{7}$ The Lone Hand was a monthly magazine published from May 1907 to February 1921, strongly associated with the rise of Australian nationalism. 
the Russo-Japanese war. He cannot believe that their presence on the island is innocent and not part of some larger strategy by the Japanese who are seeking a naval base and a coaling station in the area. The French have shown no sign of taking the menace seriously or dealing with the situation. The solution? Australia should take over the island. In doing so it would moreover be fulfilling the wishes of some, perhaps many of its French inhabitants, for the settlers, Shearston-May claims, would dearly love cession to England:

\begin{abstract}
They have a deep and abiding regard over there for the English and for the Australian. If their land cannot prosper under French rule, they say, let England have it. Let it come under the sway of Australia. If that were to follow, they all believe in their hearts that New Caledonia would once more return to old prosperity; that the Japanese would be shipped back to their own country; and that life, and work and money-making for themselves would be easier and happier. (The Lone Hand June 1911: 121-122)
\end{abstract}

Shearston-May's evidence for the views of the French settlers is left unclear - 'in their hearts' leaves room for doubt whether he has any at all. He was not, however, the only one to make such claims; letter writers to the Sydney Morning Herald made similar assertions, as the curious story of Watriama reveals. William Jacob Watriama was probably born around 1875 at Tuo village on Maré, one of the Loyalty Islands. Although he was almost certainly the son of a servant of the chiefly Naisiline clan, he claimed in later life to be the 'King of the Loyalty Isles' (Laracy 2011). He was brought up in the Protestant faith and developed a marked anglophilia that was to characterise his interventions in colonial relations between France, Britain and Australia. He settled in Sydney in 1891 where he first came to public notice in 1911 when he launched a campaign urging the end of French rule over New Caledonia and its dependencies (and also an end to the French co-administration of the New Hebrides). ${ }^{8}$ In March 1911 we find him quoted in the Sydney Morning Herald, describing hmself as the 'King of the Loyalty Islands’ and recounting suspicious activity on the part of Japanese workers on New Caledonia, who had set up a wireless station. This indicates, he is reported as saying that the Japanese 'intend eventually to form a naval base at New Caledonia in order to attack Australia' (SMH 13.03.1911: 10). The concerns of Watriama and Shearston-May meet up in a series of articles penned by the latter that were published in

\footnotetext{
${ }^{8}$ Hugh Laracy (2011) writes that Watriama is a figure of some historical interest, for he was one of the few Black men to attain a degree of acceptance in White Australian society. Much of this support was due to his war record with the AIF in France. Wounded at Pozières, he was discharged on 5 December 1917. When he died in 1925 considerable attention was paid in the newspapers and his funeral was organised and financed by the Northbridge Soldiers’ League (Evening News 06.01.1925).
} 
the Daily Herald (South Australia) also in March 1911. Six lengthy articles were published under the headline 'Only 900 Miles Away' by the Herald's 'Special Representative' over the course of a week, totalling over 21,000 words. In the article for Friday 10 March, Shearston-May interviews Watriama at length about the latter's fears, before turning to other witnesses and evidence of Japanese spying and infliltration 'in Australia's backyard’ and indeed in Australia itself. (DH 07.03.1911 to 14.03.1911)

At the end of October Watriama himself writes to the Sydney Morning Herald, railing against the presence of ' 3000 veterans of the Russo-Japanese war' on New Caledonia. These 'trained Japanese' constitute an 'increasing menace' and foretell of the invasion ‘that will surely come’ (SMH, letter dated 22.10.1911, published 25.10.1911: 21). His letter prompts a number of others in response in the following days. The first does not challenge the accuracy of Watriama's assessment of Japanese intentions but rather doubts whether representations to the French on this issue will have any effect: 'whatever the protestations of the Commonwealth may be, France will not give satisfaction' since its Republican principles compel it to be the 'nation the most hospitable of the world.' The tone of the letter suggests that the writer does not find this hospitality to be an admirable trait (SMH 26.10.1911: 13). The discussion continued through November and December in both editorials and letters. On 4 December The Sydney Morning Herald suggests that advantage be taken of negotiations between France and Britain over the New Hebrides to discuss 'Pacific matters' including the situation in New Caledonia. The paper claims, in an echo of the Lone Hand article, that a 'movement' in New Caledonia has recently been formed to campaign for the transfer of power to the British (SMH 04.12.1911: 8).

\section{Conclusion}

During the three periods of tension in the relations between Australia and New Caledonia examined in this article, the anxiety and uncertainty provoked by the rapidly evolving geopolitical situation in the Pacific were heightened by the very proximity of New Caledonia. Some never gave up the hope that the French colony would return to the British fold, the only way of ensuring that it would not constitute a 'trojan horse,' first for French, then for Japanese incursion into the region. These fears provoked common themes and perennial complaints about the French: that they were poor colonial administrators; that New Caledonia was a backward and festering sore in the 
Pacific, a source of criminality and disease through the persistence of the penal colony (deportation continued until 1897); that it was unsuccessful in agriculture and the development of cash crops; and that it remained under the total control of the French government (and a Republican one at that, from 1875), failing to develop the institutions of local governance that the Australian colonies achieved progressively from the early nineteenth century. As late as 1915, when France and Britain were allies once again and Australian troops were fighting alongside them at Gallipoli, the respected economist R. C. Mills, calling for recognition of the 'achievements of Wakefield in colonization and colonial policy' and in the British annexation of New Zealand, wrote: 'New Zealand, lost to the French, might have become a second Noumea, and another plague spot in the Pacific' (Mills 1915: 340).

As Australians compared and contrasted their own society, institutions of governance and practices of colonisation to those of New Caledonia, ruled by 'a rival nation, whose aims and objects are so dissimilar, not to say opposite, to those which have for many years been earnestly contemplated by the most intelligent colonists of Australia and of New Zealand' (SMH 02.11.1853: 4), these assumed differences became markers of distinction and identity. Indeed a four-sided relationship was created by the presence of the French on New Caledonia: Australian settlers/Britain/French settlers/France, forming a complex web of relations within which the Australians had to conceive and negotiate the terms of their own presence in the Pacific. Historians have drawn attention to the significance of hostility to Chinese workers and Kanakas (a few of whom came from New Caledonia) in developing an Australian national consciousness (McMinn 1994: 123-4). But the constant comparisons that the newspapers engage in, to the detriment of their French neighbours, suggest that this consciousness was also forged in the uneasy cohabitation of Australian and French colonists in this long isolated corner of the Pacific.

\section{Reference List}

Cannon, M. (ed). 1983, 'Introduction,' The Vagabond Papers. Abridged, $2^{\text {nd }}$ edition. Hyland House, Melbourne.

Donohoo, J. 2013, 'Australian Reactions to the French Penal Colony in New Caledonia,' Explorations, v. 54: 25-45.

Dousset-Leenhardt, R. 1978, Colonialisme et Contradictions: Nouvelle-Calédonie 1878-1978. L'Harmattan, Paris.

Kuypers, J. 2009, 'Framing Analysis,' Rhetorical Criticism: Perspectives in Action. Lexington Books, Plymouth: 181-204. 
Laracy, H. 2011, Watriama and Co: Further Pacific Islands Portraits. Australian National University Press, Canberra.

Lyons, M. 1986, The Totem and the Tricolour: A Short History of New Caledonia Since 1774. NSW University Press, Kensington, NSW.

McMinn, W. G. 1994, Nationalism and Federalism in Australia. Oxford University Press Australia.

Meaney, M. 2007, Towards a New Vision: Australia and Japan Across Time. NSW University Press, Kensington,NSW.

Merle, I. 1995, Expériences coloniales: La Nouvelle-Calédonie (1853-1920). Edns Belin, Paris.

Mills, R. C. 1915, The Colonization of Australia. Sidgwick \& Jackson, London.

Parkes, H. 1876, Speeches on Various Occasions Connected with the Public Affairs of NSW. Longmans, Green and Co, London \& Lebourne.

Pons-Ribot, G. (ed). 1989, La guerre en Nouvelle-Calédonie (1878). La Petite Maison, Boulogne.

Parsons, G. 1967, 'New Caledonian Convicts in New South Wales 1876-1884,' Journal of the Royal Historical Society, v. 52, no. 6: 51-67.

Shearston-May, A. K. 1911, 'New Caledonia: A Menace to White Australia: The Remarkable Colony of Japanese Who have become Australia's Nearest Neighbor,' The Lone Hand, June: 117-122.

Speedy, K. 2013, ““After Me Fellow Caïcaï You”: Eating The Other/The Other Eating,' Portal Journal of Multidisciplinary International Studies, Special Issue: Edible Alterity, v. 10, n. 2. Online, available: http://epress.lib.uts.edu.au/journals/index.php/portal/article/view/2971 [Accessed 1 November 2014].

Stanley, P. 2008, Invading Australia: Japan and the Battle for Australia. Viking, Camberwell, Vic.

Walker, D. 1999, Anxious Nation: Australia and the Rise of Asia 1850-1939. University of Queensland Press, St Lucia.

\section{List of Newspapers Cited (Abbreviation) and Date of First Publication}

Age (Melbourne) (Age) 1854

Argus (Melbourne) (AR) 1846

The Australian (Sydney) (Aust) 1824

Brisbane Courier (BC) 1864

Courier (Hobart) (CH) 1840

Daily Herald (Sth Aust) (DH) 1910

Evening News (Sydney) (EN) 1869

Illustrated Sydney News (ISN) 1853

Maitland Mercury (MM) 1843

Moreton Bay Courier (Queensland) (MBC) 1846

South Australian Advertiser (Adelaide) (SAA) 1858

South Australian Register (Adelaide) (SAR) 1839

Sydney Morning Herald (SMH) 1831

Using the search engine of the Australian National Library's Trove collection of digitised newspapers, all articles, editorials and letters devoted to 'New Caledonia' were identified and read for the periods 01.09.1853 to 01.01.1854; 20.06.1878 to 31.12.1878; and the years 1911-1912. 